\title{
Empirical models for predicting the spatial variation of soil thickness and shear strength for landslide susceptibility assessment
}

\author{
${ }^{*}$ Cheryl F. Daleon ${ }^{1}$ and Glen A. Lorenzo ${ }^{2}$ \\ ${ }^{I}$ Central Mindanao University, Maramag, Bukidnon, Philippines \\ ${ }^{1,2}$ Mindanao State University-Iligan Institute of Technology (MSU-IIT), Iligan City, Philippines \\ *Corresponding author: cheryl_daleon@yahoo.com.ph
}

\begin{abstract}
Spatial variation of soil thickness, cohesion and friction angle are crucial in large scale slope stability analysis. However, determination of these parameters is challenging, costly and time consuming. In order to opt out expensive laboratory tests and laborious field investigation, efforts had been done by many researchers to predict these parameters over large areas. In this study, the soil samples and soil thickness data are gathered from 30 sampling boreholes and 60 probed points in an area with Pliocene-Pleistocene geology. The details on slope angle are obtained from the slope map through a processed Digital Elevation Model (DEM) in Geographic Information System (GIS) particularly the ArcGIS software. Slope angles are confirmed in the site through actual measurement using the clinometer. The soil thickness is measured from the ground surface down to the interface of soil and weathered bedrock. The cohesion and friction angle are determined from the direct shear test. Regression analysis is used to establish an empirical model correlating the soil thickness and shear strength parameters with the slope angle. The result revealed that the slope angle has yielded better correlation to the soil thickness than the cohesion and friction angle. The resulting slope angle-soil thickness empirical model is validated from ten different sites with similar geology.
\end{abstract}

Keywords: Cohesion, Empirical model, Friction angle, Slope angle, Soil thickness

Paper Received: 31 Jan 2018

Paper Accepted: 25 March 2018

\section{INTRODUCTION}

Landslides are the most widespread natural hazard on earth and had been a problem of many countries worldwide. In the Philippines, landslides are among the major geologic hazards that resulted to thousands of lives lost and millions of pesos of economic damage over the years (Opiso et al., 2014). Thus, in a country that is mostly hilly and mountainous, utilization of land on slopes is inevitable. It is therefore very important to map out unstable areas to ensure the safety of the people and delineate suitable areas for development (Rabonza et al., 2014).

There are available deterministic methodologies in landslide hazard assessment, one of which is by using the concept of infinite slope model under limit equilibrium method (Soeters and Van Westen, 1996). Usually the soil parameters and causal factors for shallow landslide are manipulated in a GIS platform. The spatial variation of soil thickness, cohesion and friction angle are required in order to come up a landslide hazard map. However, applying purely quantitative approach in large area requires laborious field investigations and costly laboratory experiments. Acquisition of input data such as soil thickness and soil strength parameters demands an intensive field investigation and expensive laboratory test. Therefore, a model is developed in order to mitigate these problems.

The different methods of determining the spatial variation of soil thickness from previous studies are presented by (Kim et al., 2005). A uniform soil thickness was used in previous analyses of shallow landslides (Montgomery and Dietrich, 1994; Dietrich et al., 1995; Wu and Sidle, 1995; Kim et al., 2005) and some researchers included sparse soil thickness sampling data in the analysis of slope stability. However, the wetness index was adopted to determine the spatial distribution of soil thickness for slope instability analysis (Lee and Ho, 2009). These methods will make the application of infinite slope model possible, yet it will not lessen the uncertainties of the input parameter particularly the soil thickness.

In addition, the accurate measurement of shear strength can be difficult, time consuming and costly (Obasi and Anyaegbunam, 2005). He added, as a result of this there is now a tendency in countries all over the world towards building up correlation equations between the above soil properties and the so-called soil indices in order to speed-up the design process. This is most pertinent in third world countries where up-to-date testing equipment are lacking together with the trained manpower needed to operate them.

On the other hand, slope angle can be easily obtained through the slope map of a processed DEM from government agency conducting mapping projects like Phil-LIDAR (Philippine-Light Detection and Ranging). Moreover, during the field investigation, slope angle can be verified and actually measured using the clinometer. 
Hence, in a country where project's budget allocation is limited and time aspect is relevant, improving available methodology through the development of an empirical model that speed-up the landslide hazard mapping in large areas at minimized cost will help resolve these problems.

\section{METHODOLOGY}

\section{Study area}

Field investigation and soil sampling were conducted in barangays New Kidapawan and Kiorao, Kibawe, Bukidnon, Philippines. The study area is underlain by Basaltic Andesite geology with Pliocene-Pleistocene origin. The residual soils that masked the surface are brown to dark yellowish brown fine-grained soils. Most of the recorded landslide events in the municipality had occurred in this type of geology.

\section{Soil thickness determination}

The data collection was conducted through random soil sampling. With reference to the 10 slope ranges, the sampling points were selected and pinned in the working map or slope angle map generated from the GIS. There are 3 boreholes and 6 probed points assigned for each slope range to have an equal distribution of data in the derivation of the model. A total of 30 boreholes and 60 probed points were distributed all throughout the area within the 10 slope ranges. The soil thickness was measured from the soil surface down to the interface of soil and the weathered bedrock. The actual slope angle of the site was measured using a clinometer while soil thickness was measured by a measuring tape. Aside from the boreholes, there was a total of 60 probed points used to obtain additional data of soil thickness.

\section{Drained shear strength determination}

Determination of the shear strength of the soil sample was based on ASTM D 3080. In this laboratory test, a direct shear device was used to determine the cohesion (c) and the friction angle $(\phi)$ of the soil. From the plot of the shear stress versus the horizontal displacement, the maximum shear stress was obtained for a specific vertical confining stress. After the experiment was run several times for various vertical-confining stresses, a plot of the maximum shear stresses versus the vertical (normal) confining stresses for each of the tests was produced. From the plot, a straight-line approximation of the MohrCoulomb failure envelope curve can be drawn, cohesion and friction angle were determined based on the equation

$$
\tau=\sigma^{\prime} \tan \phi^{\prime}+c^{\prime}
$$

A total of 10 soil samples (3 soil samples each for $\mathrm{CH}$ and MH soils; and 2 soil samples each for CL and ML soils) distributed to 10 different slope ranges were taken to direct shear test.

\section{Correlation of parameters}

The soil parameters such as soil thickness, cohesion and friction angle were correlated with the slope angle. In order to derive an empirical model, the regression analysis through MS Excel application was used to manipulate the data and formulate correlations between the parameters. Akayuli and Ofosu (2013) that the assessment of regression relationships was done through estimation of coefficient of determination, $\left(\mathrm{R}^{2}\right)$. For $\mathrm{R}^{2}$ with value of 0.5 means that 50 percent of the variation in the independent variable is being explained by the dependent variable. An $\mathrm{R}^{2}$ value of 0.0 means that there is no correlation between the variables, an $\mathrm{R}^{2}$ value of 1 means that there is a perfect correlation between the variables.

\section{Model validation}

The derived empirical equation was used to predict the soil thickness of other 10 sites which were not used in the regression analysis. The validation site is from different location but of the same geology with the study area. The predicted values were plotted against the measured soil thickness. The quality of a regression relationship depends on the ability of the relationship to predict the dependent variable for observation on the independent variables that were not used in estimating the regression coefficients (Haan, 1994; Akayuli and Ofosu, 2013).

\section{RESULTS AND DISCUSSIONS}

\section{Correlation of soil thickness with the slope angle}

The relationship between soil thickness and slope angle is best described by an exponential function, as shown in Fig. 1. The same observation was made by (Tan et al., 2008; Salciarini et al., 2006; De Rose, 2009). The result of field investigation in this study has confirmed to the general observation being cited in the literature that soil thickness decreases with increasing slope angle. The average depths are $2.16 \mathrm{~m}$ for gentler slopes $\left(<28^{\circ}\right)$, decreases to about $1.0 \mathrm{~m}$ for the modal class slopes $\left(28^{\circ}-32^{\circ}\right)$, and to more or less $0.5 \mathrm{~m}$ for the steepest slopes $(>$ $\left.32^{\circ}\right)$. The slope angle-soil thickness empirical model has yielded high coefficient of determination $\mathrm{R}^{2}$ of 0.9284 , which simply means that there is high correlation between these two parameters. Hence, the resulting equation is a good empirical model to be used in predicting the spatial distribution of soil thickness with less uncertainty especially over a large area with PliocenePleistocene geology.

The good correlation of soil thickness and slope angle is attributed to the fact that steeper slope has accelerated erosion. If rate of erosion is greater than rate of soil development, then it will result to thin or no soil. On the other hand, soil in lowlying areas or with gentler slopes has higher water content and 


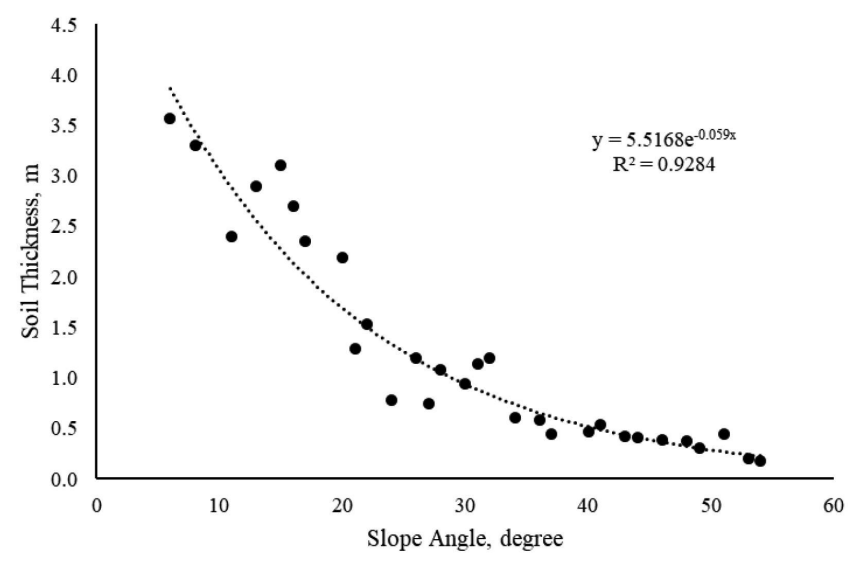

Fig. 1: Soil thickness as a function of slope angle (Exponential Series)

accelerated weathering, resulting to thicker soils.

Table 1 presents the values of shear strength parameters particularly the cohesion and friction angle from various soil classifications with the corresponding slope angles.

Based on the average cohesion value of each soil classification, $\mathrm{CH}$ has the highest cohesion of $21.67 \mathrm{kN} / \mathrm{m}^{2}$ while ML has the lowest value of $19.60 \mathrm{kN} / \mathrm{m}^{2}$. It also shows that $\mathrm{CH}$ has the highest plasticity index (PI) while having the highest cohesion. On the other hand, ML has the lowest PI while having the lowest cohesion. It indicates that the cohesion value increases with decreasing value of PI. It was stated that highly plastic soils have high cohesion value and as the plasticity becomes lower the cohesion value also decreases (Mammoli, 2011).

On the same table, the average values show that $\mathrm{CH}$ has the highest friction angle of $14.63^{\circ}$ while CL has the lowest value of $11.15^{\circ}$ with a slight difference to ML with 11.85 degrees. Generally, friction angle decreases with the increase of PI value. However, Table 1 shows that for CL and ML soils, friction angle slightly decreases from $11.85^{\circ}$ to $11.10^{\circ}$, with increasing PI. However, it shows that for $\mathrm{CH}$ and $\mathrm{MH}$ soils, friction angle increases with increasing PI. This relationship may seem unusual, but it may imply that there are other parameters that can give better correlation of friction angle especially for highly plastic clay.

A study was conducted on the two different clays by (Gourlay and Wright, 1984). From their resulted friction angles and PI values, it is observed that it had the same case with the result of this study in two ways: first, the red and the grey Beaumont clays, like CL and ML, have almost the same friction angles with different PI values; second, like $\mathrm{CH}$ and $\mathrm{MH}$, they have increasing friction angles with increasing PI. Moreover, the data of the study on shear strength correlations of highly plastic clay soils for the red and the grey Beaumont clays demonstrated the difficulty that may be encountered in correlating the effective stress friction angle to the PI or the LL (Saleh and Wright, 1997). Both soils exhibited almost the same friction angle, but had different PI and LL. They added that based on the results of the study shown by (Stark and Eid, 1994), it is possible for two soils to have the same friction angle but different LL, provided the soils have different clay size fractions. Unfortunately, results reported in the literature usually report clays having clay size fractions greater than 50 percent as one group of soils with no further distinction. Hence, (Lupini and Skinner, 1981; Skempton, 1985; Saleh and Wright, 1997) suggested that clay size fraction and mineralogy are probably the most important parameters in estimating the residual friction angle.

\section{Correlation of cohesion with the slope angle}

Fig. 2 shows the correlation of cohesion with the slope angle. The best fitting model is a power series. With $\mathrm{R}^{2}=0.7326$, it means that more than $50 \%$ of the cohesion can be predicted by slope angle and the equation can be used to predict the cohesion in the area with less uncertainty.

Fig. 3 shows an improved correlation of cohesion with the slope angle, specified for slope angles from $27^{\circ}$ up to the steepest slopes. The $\mathrm{R}^{2}=0.8633$, shows that there is a good correlation between the two parameters.

Table 1: Shear strength parameters and PI of soil

\begin{tabular}{|c|c|c|c|c|c|c|c|}
\hline $\begin{array}{c}\text { Soil } \\
\text { Classification } \\
(\mathrm{USCS})\end{array}$ & $\begin{array}{l}\text { Sampling } \\
\text { Code }\end{array}$ & $\begin{array}{c}\text { Actual Slope } \\
\text { (degree) }\end{array}$ & $\begin{array}{l}\text { Cohesion } \\
\left(\mathrm{kN} / \mathrm{m}^{2}\right)\end{array}$ & $\begin{array}{l}\text { Average } \\
\text { Cohesion } \\
\left(\mathrm{kN} / \mathrm{m}^{2}\right)\end{array}$ & $\begin{array}{l}\text { Friction } \\
\text { Angle } \\
\text { (degree) }\end{array}$ & $\begin{array}{c}\text { Average } \\
\text { Friction Angle } \\
\text { (degree) }\end{array}$ & $\begin{array}{l}\text { PI } \\
(\%)\end{array}$ \\
\hline \multirow{3}{*}{$\mathrm{CH}$} & $\mathrm{BH} 4$ & 13 & 19.8 & \multirow{3}{*}{21.67} & 10.8 & \multirow{3}{*}{14.63} & \multirow{3}{*}{48.60} \\
\hline & BH19 & 36 & 20.6 & & 16.9 & & \\
\hline & $\mathrm{BH} 28$ & 48 & 24.6 & & 16.2 & & \\
\hline \multirow{3}{*}{ MH } & BH1 & 6 & 11.4 & \multirow{3}{*}{20.0} & 16.9 & \multirow{3}{*}{13.53} & \multirow{3}{*}{28.53} \\
\hline & BH7 & 17 & 17.7 & & 14.1 & & \\
\hline & $\mathrm{BH} 22$ & 40 & 30.9 & & 9.6 & & \\
\hline \multirow{2}{*}{$\mathrm{CL}$} & BH17 & 32 & 19.6 & \multirow{2}{*}{20.1} & 14.1 & \multirow{2}{*}{11.10} & \multirow{2}{*}{26.19} \\
\hline & $\mathrm{BH} 24$ & 43 & 20.6 & & 8.1 & & \\
\hline \multirow{2}{*}{ ML } & $\mathrm{BH} 13$ & 27 & 16.1 & \multirow{2}{*}{19.6} & 15.7 & \multirow{2}{*}{11.85} & \multirow{2}{*}{16.07} \\
\hline & $\mathrm{BH} 29$ & 51 & 23.1 & & 8.0 & & \\
\hline
\end{tabular}




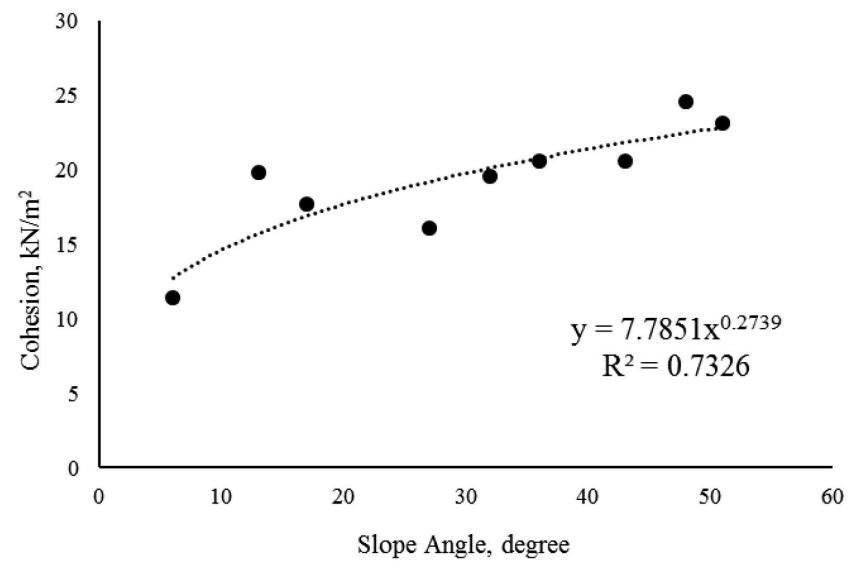

Fig. 2: Cohesion as a function of slope angle (Power Series)

The trend in the graph shows that cohesion increases with increasing slope angle. The variation of cohesion on its corresponding slope angle is shown in Fig. 4 based on each soil classification. It shows that for all soils, cohesion increases with the increasing slope angle. Cohesion usually does not increase

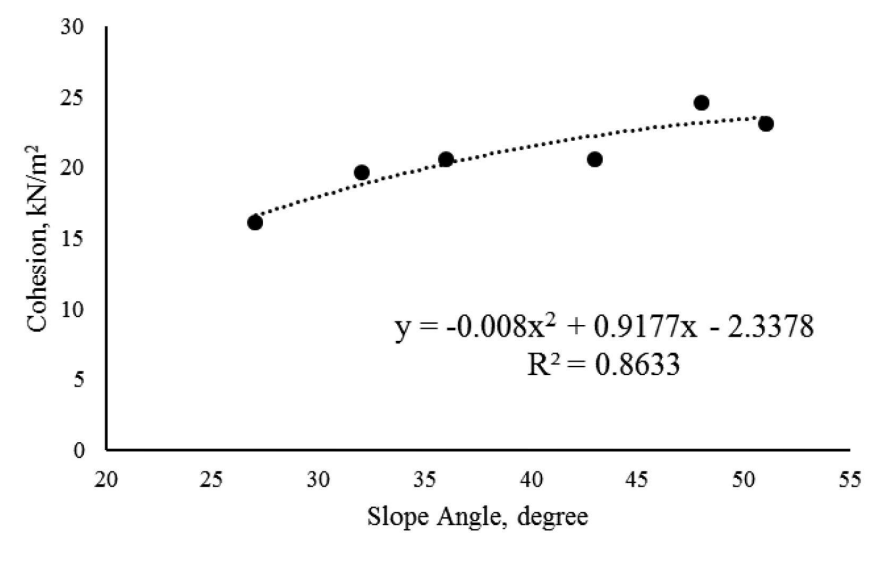

Fig. 3: Cohesion - slope angle correlation for slope angles $=27^{\circ}$ (Polynomial Series)

with increasing stress, except for clayey soils, where the increase in stress causes increase in molecular binds (Blahova et al., 2013). It is evident in the result that there is an increase in cohesion with increasing slope angle, with increase in stress.
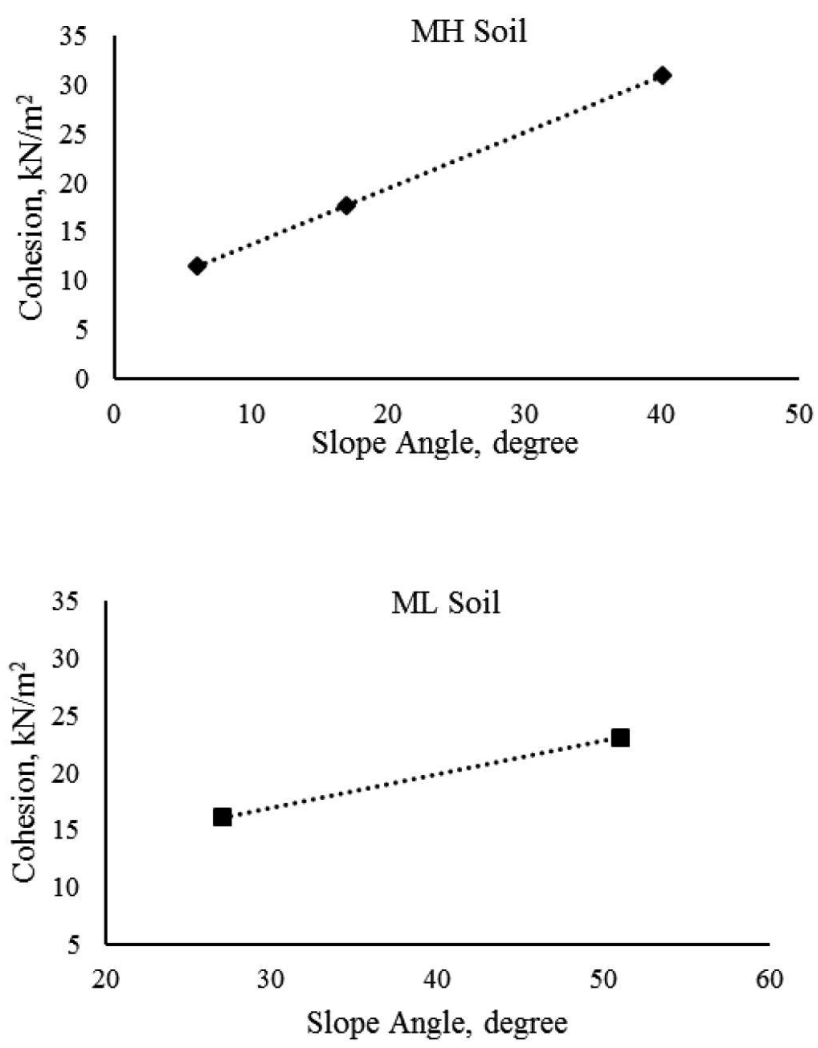

Fig. 4: Cohesion - slope angle relationship per soil classification 


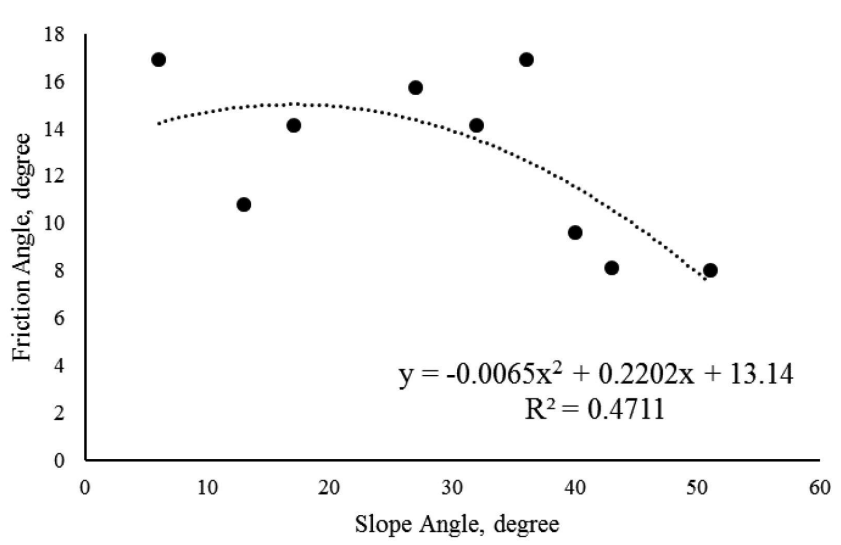

Fig. 5: Friction angle as a function of slope angle (Polynomial Series)

\section{Correlation of friction angle with the slope angle}

The angle of internal friction is a parameter of the degree of interlocking of individual grains or aggregates which itself depends on shape, roundness, size and packing arrangement of the particles (Steinacher et al., 2009). These factors are not directly influenced by the slope angle. That may cause the low correlation of the two parameters.

Moreover, the low correlation between friction and slope angle can be attributed to the fact that the model is derived from the test results of four different soil classifications which have different physical characteristics such as shapes, roundness, size and etc. Fig. 5 shows the graph of friction angle as a function of slope angle. The $\mathrm{R}^{2}$ value indicates that the parameter slope angle cannot predict at least $50 \%$ of the friction angle in the regression analysis. Thus, using this correlation to predict the friction angle in the study area will mean a high uncertainty on the resulting predicted values. However, a better correlation between the two parameters is shown in Fig. 6. It is applicable for slope angles from $27^{\circ}$ up to the steepest slopes. An improved value of $\mathrm{R}^{2}=0.903$ means that prediction of friction angle in the area using the specified slope angles will have a lesser uncertainty.

From the derived correlations it is proposed to have a constant friction angle from gentler slopes up to $27^{\circ}$, then beyond, the exponential function is used. Fig. 7 shows the proposed model for the correlation of friction angle with the slope angle.

The overall trend of the correlation between the two parameters shows that friction angle decreases with the increasing slope angle. The decrease in friction angle with increasing slope angle can clearly be seen if values are classified based on soil classification as shown in Table 1 and Fig. 8.

\section{Model validation}

In order to verify the equation between the soil thickness and the slope angle, the empirical equation obtained was used

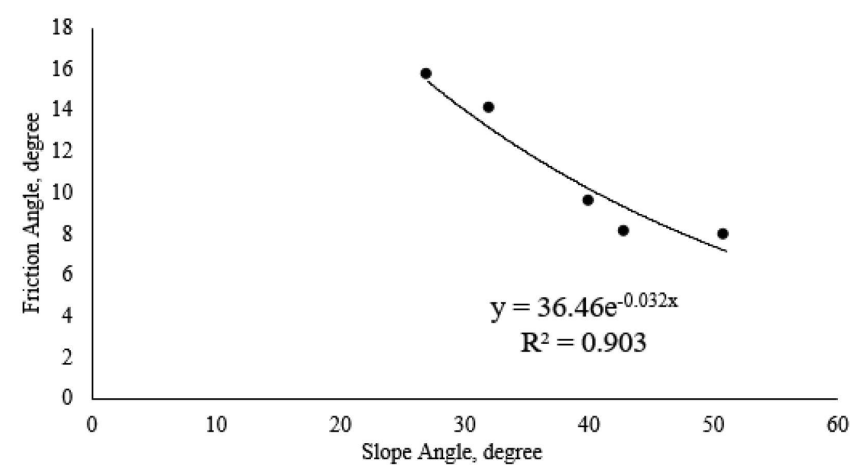

Fig. 6: Friction angle - slope angle correlation for slope angles $=27^{\circ}$ (Exponential Series)

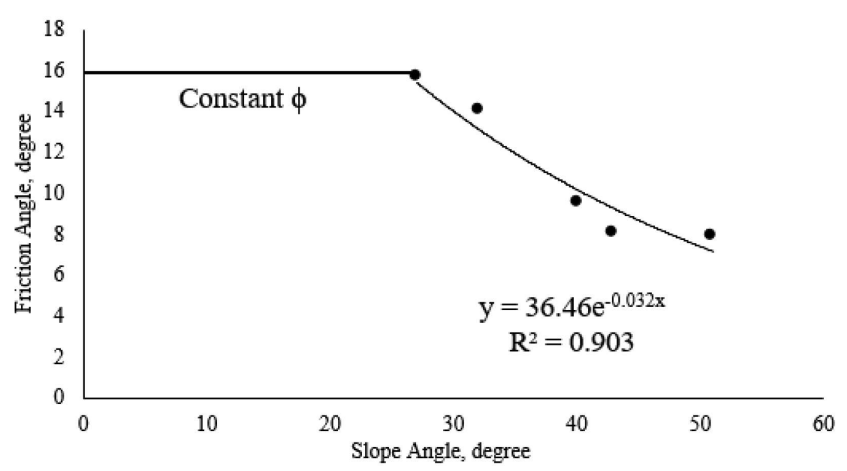

Fig. 7: Proposed model for friction angle - slope angle correlation

to predict the soil thickness of the other 10 sites which were not used in the regression analysis. Fig. 9 shows the graph for validation of the model. The high $\mathrm{R}^{2}$ of 0.9326 for the relationship between the predicted and the measured soil thickness indicates that the established equation is valid and can be used to predict soil thickness using the slope angle in areas with residual soils of basaltic andesite geology, with less uncertainty.

\section{CONCLUSIONS}

The slope angle has yielded high correlation on the soil thickness. The high correlation of soil thickness with the slope angle means that the derived model can be used to predict the spatial variation of soil thickness with less uncertainty. The empirical model was successfully validated; hence, it can be used to predict soil thickness of other locations of the same geology. Moreover, it is hypothesized that the model is valid only for modeling the spatial variation of soil thickness with slope angle of residual soil of basaltic andesite mountain slopes. The empirical model can be used for large scale landslide susceptibility analysis in mountain slopes using infinite slope model. It can be used for other geohazards analysis that will require spatial variation of soil thickness. On the other hand, 

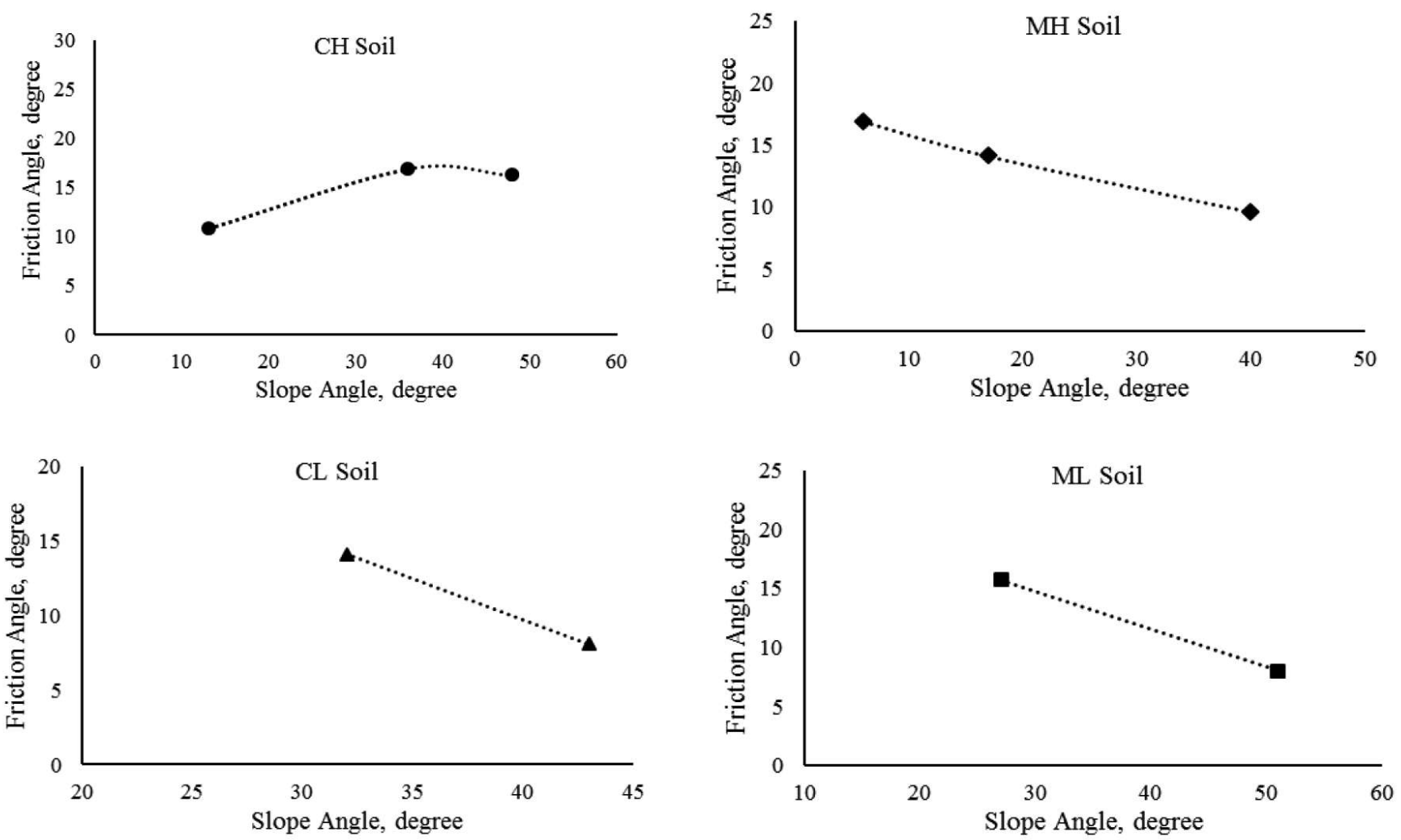

Fig. 8: Friction angle - slope angle relationship per soil classification

this study has found out that the slope angle has yielded correlation to strength parameters, cohesion and friction angle, only from good to fair, respectively, which could be further verified due to the limited data of cohesion and friction angle used in this study.

\section{ACKNOWLEDGEMENT}

The authors would like to thank the Department of Science and Technology-Engineering Research and Development

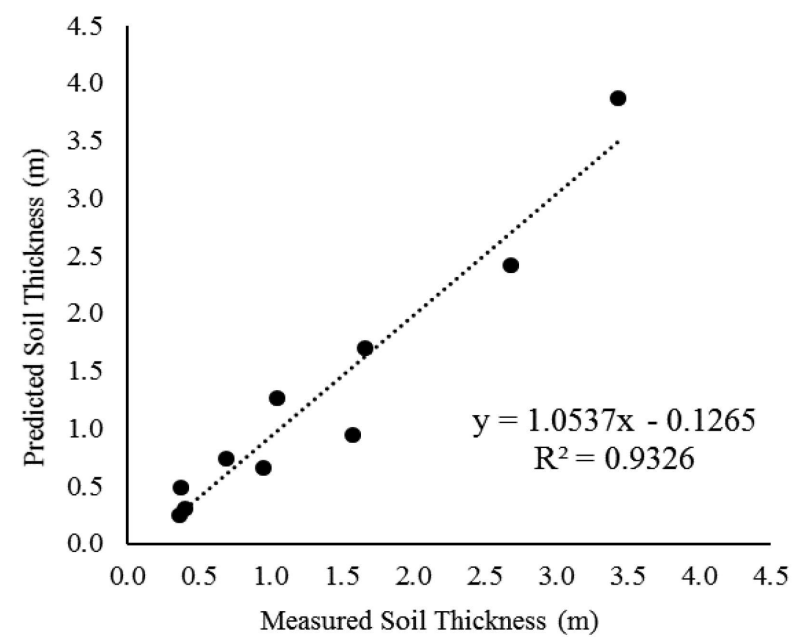

Fig. 9: Validation of the model for Technology (DOST-ERDT) Philippines for the scholarship and research grant of this study.

\section{REFERENCES}

Akayuli, C. F. A. and Ofosu, B., 2013, Empirical model for estimating compression index from physical properties of weathered Birimian Phyllites. CSIR-Building and Road Research Institute. EJGE, v. 18, pp. 6135-6144.

Blahova, K.., Ševelova, L., and Pilaøova, P., 2013, Influence of water content on the shear strength parameters of clayey soil in relation to stability analysis of a hillside in BRNO Region, Acta Universitatis Agriculturae et Silviculturae Mendelianae Brunensis, v. LXI, pp. 1583-1588.

De Rose, R. C., 2009, Quantifying sediment production in steepland environments, Eurasian J. For. Res., v. 12, no. 1, pp. 9-46, Hokkaido University Forests, EFRC.

Dietrich, W. E., Reiss, R., Hsu, M., and Montgomery, D. R., 1995, A process-based model for colluvial soil depth and shallow landsliding using digital elevation data, Hydrol. Process, v. 9, pp. 383-400.

Gourlay, A. W. and Wright, S. G., 1984, Initial laboratory study of the shear strength properties of compacted, highly plastic clays used for highway embankment construction in the area of Houston, Texas, A Report on Laboratory Testing Performed under Interagency Contract Numbers 
(82-83) 2187 and (84-85) 1026, Center for Transportation Research, The University of Texas at Austin.

Haan, C. T., 1994, Statistical methods in hydrology, Affiliated East-West Press Pvt. Ltd. New Delhi, India.

Kim, M. S., Ondal, Y., and Kim, J. K., 2015, Improvement of shallow landslide prediction accuracy using soil parameterisation for a granite area in South Korea, Nat. Hazards Earth Syst. Sci. Discuss., v. 3, pp. 227-267.

Lee, K. T. and Ho, J. Y., 2009, Prediction of landslide occurrence based on slope-instability analysis and hydrological model simulation, J. Hydrol., v. 375, pp. 489-497.

Lupini, J. F. and Skinner, A. E., 1981, The drained residual strength of cohesive soils," Geotechnique, vol. 31, no. 2.

Mammoli, A. A., Brebbia, C. A., and Klemm, A., 2011, Materials Characterization Five, WIT Transactions on Engineering Sciences, v. 72, pp. 316, ISSN 1743-3533.

Montgomery, D. R. and Dietrich, W. E., 1994, A physically based model for the topographic control on shallow landsliding, Water Resour. Res., v. 30, pp. 1153-1171.

Obasi, N. L. and Anyaegbunam, A. J., 2005, Correlation of the undrained shear strength and plasticity index of tropical clays, Nigerian Journal of Technology, v. 24, no. 2.

Opiso, E. M., Puno, G. R., Detalla, A. L., and Alburo, J. P., 2014, Rainfall-induced landslide susceptibility zonation along the Cagayan de Oro City - Bukidnon -Davao City Route Corridor, KCE, Journal of Civil Engineering, v. 20, no. 6, pp. 2506-2512

Rabonza, M. L., Felixa, R. P., Ortiza, I. J. G., Alejandrinoa, I. K. A., Aquinoa, D. T., Ecoa, R. C., and Lagmaya, A. M. F. A., 2014, Shallow landslide susceptibility mapping for selected areas in the Philippines severely affected by Supertyphoon Haiyan, Project NOAH open-file reports. ISSN 2362 7409, v. 3, pp. 28-36.
Salciarini, D., Godt, J. W., Savage, W. Z., Baum, R. L., and Conversini, P., 2006, Modeling regional initiation of rainfall-induced shallow landslides in the Eastern Umbria Region of Central Italy, using the TRIGRS (Transient Rainfall Infiltration and Grid-based Slope-Stability) Approach, Researchgate [Online]. Available: .

Saleh, A. A. and Wright, S. G., 1997, Shear strength correlations and remedial measure guidelines for long-term stability of slopes constructed of highly plastic clay soils, Research Project, Center for Transportation Research, Bureau of Engineering Research, The University of Texas Austin.

Skempton, A. W., 1985, Residual strength of clays in landslides, folded strata, and the laboratory, Geotechnique, v. 35, no.1, Geotechnique 35(1), pp. 3-18.

Soeters, R. and Van Westen, C., 1996, Slope instability recognition, analysis, and zonation. Landslides: Investigation and mitigation special report 247 , Transportation Research Board National Research Council, pp. 129-173.

Stark, T. D. and Eid, H. T., 1994, Drained residual strength of cohesive soils, ASCE Journal of Geotechnical Engineering, v. 120 , no.5, pp. $856-871$.

Steinacher, R., Medicus, G., Fellin, W., and Zangerl, C., 2009, The influence of deforestation on slope (in-) stability, Austrian Journal of Earth Sciences, v. 102, no. 2, pp. 90-99.

Tan, C. H., Ku, C. Y., Chi, S. Y., Chen, Y. H., Fei, L. Y. , Lee, J. F., and Su, T. W., 2008, Assessment of regional rainfallinduced landslides using 3S-based hydro-geological model, Landslides and Engineered Slopes, ISBN 978-0-41541196-7.

Wu, W. and Sidle, R. C., 1995, A distributed slope stability model for steep forested basins," Water Resour. Res., v. 31, pp. 2097-2110. 
